Our Nature (2005)3:56-62

\title{
Status and Distribution of Blue Sheep, Tibetan Argali and the Kiang in Damodar Kunda Area, Upper Mustang, Nepal
}

\author{
M. Chetri and A. Pokharel ${ }^{1}$ \\ King Mahendra Trust for Nature Conservation \\ ${ }^{1}$ Institute of Forestry, Pokhara \\ E-mails:mchetri@kmtnc-acap.org.np/anita1550@yahoo.com
}

\begin{abstract}
During September 2003, status and distribution of blue sheep, Tibetan argali and kiang was studied in Damodar Kunda area. A total of twelve days were expended in the field for data collection. Areas suspected for high faunal diversity were visited and searched out using binoculars and Nikon spotting scope. Altogether 395 blue sheep $(\mathrm{N}=21)$ were recorded. The percentage of female was comparatively higher $(n=116)$ than the male $(n=65)$, yearling $(n=32)$ and lamb $(n=52)$. The ratio of male to female observed during the survey was $1: 2$ and the ratio of female to lamb is $2: 1$ respectively. Mean group size was 18.8 individuals with a density of $5.6 / \mathrm{sq}$. kms. Seventy seven individuals of Tibetan argali $(\mathrm{N}=4)$ were recorded. Mean group size is 19.3 individuals with a density of $1.1 / \mathrm{sq} \mathrm{km}$. Fifty five individuals of Tibetan wild ass $(\mathrm{N}=10)$ were recorded. Mean group size was 5.5 individuals with a density of $0.8 / \mathrm{sq}$. km. Upper Damodar Kunda valley is less disturbed compared to lower valley but most parts are barren and have desert like environment. The disturbances caused by livestock grazing and herders camp have direct impact on the wildlife population of the region.
\end{abstract}

Key words: Conservation, Distribution, Disturbances, Status

\section{Introduction}

Distribution of herbivore population mainly relates to abundant forage, water, escape cover and disturbances. All these criteria are met by Damodar Kunda area in terms of both floral and faunal elements (Koirala and Shrestha, 1997; Shah, 2003a). Damodar Kunda encompasses a small valley (71.15 sq. $\mathrm{km}$.) bordered by Khumjung Himalayan range in south, Gaugiri and Tibet Autonomous Region of China in north, Dolpa district in north-east, and settlements of Ghara, Yara, Dhi and Surkhang villages in west. The region serves a catchment area of Bokshi Khola, Namta Khola and Bharse Khola, which are prominent tributaries of Dhyechyang Khola, which finally meets the Kali Gandaki river, an important migratory corridor for avifauna. The topography of the area consists of the flat undulating terraces to extremely steep barren slopes. Its vegetation consists of scrub bushes, forbs and alpine meadows and vertical topography ranges from 5000-6581 m.

Although kiang, Tibetan argali and blue sheep are reported from other areas in Upper Mustang (Shah, 2003a; Chetri, 2004a; 2004b; Pokharel, 2006), Damodar Kunda valley is the only area where the three species are confined. The region also harbors other rare and endangered Trans-Himalayan fauna like snow leopard, lynx, grey wolf, red fox and brown bear. The area is also famous for the Hindu pilgrimage and is considered as one of the most important sacred place. From different parts of Nepal and India, hundreds of pilgrims annually visit the area. 
M. Chetri and A. Pokharel / Our Nature (2005)3:56-62

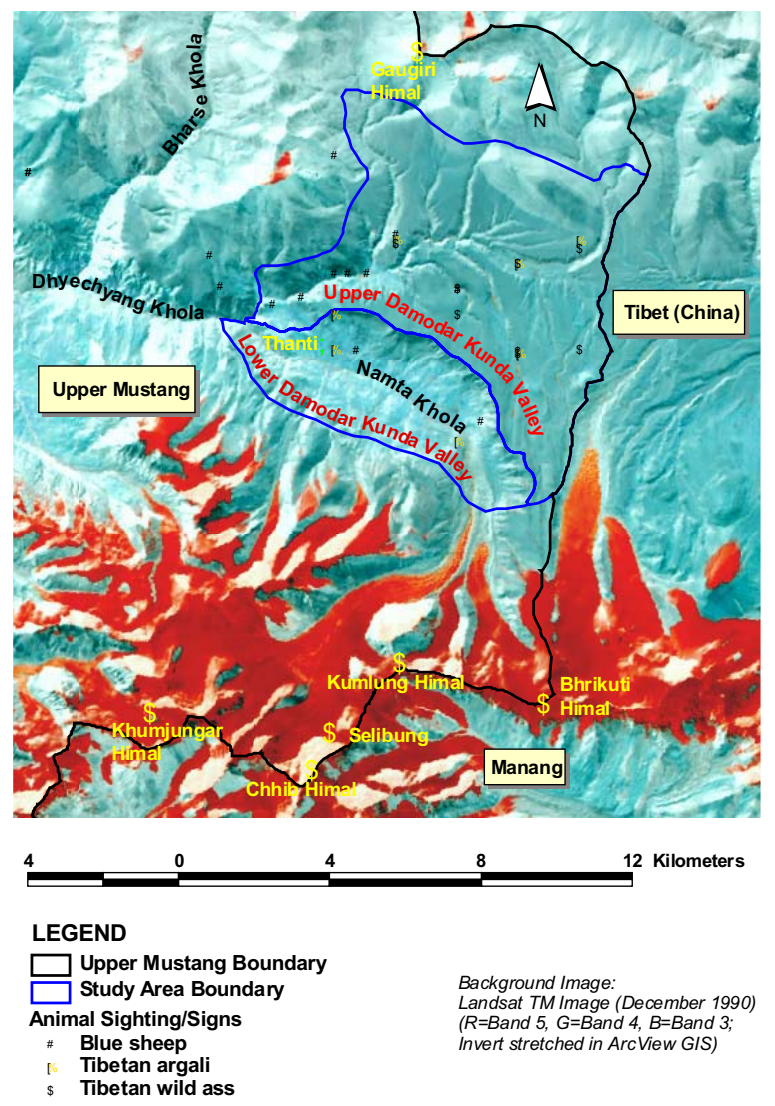

Figure 0. Map of the distribution of blue sheep, Tibetan argali and kiang in the study area

Despite its richness, few research and Materials and Methods surveys work haves been done in this area Survey for large herbivores (Koirala and Shrestha, 1997; Shah, 2003a; A survey of blue sheep, Tibetan argali and Chetri, 2004b). In this paper an attempt has kiang was conducted along the trail and been made to document the status and nearby areas either through the unaided eyes distribution of blue sheep, kiang and Tibetan or by using binoculars and spotting scopes. argali which are the most important mam- Areas suspected for high faunal diversity malian species of the region. This work is a were visited and searched out by using part of the broader biodiversity survey binoculars and Nikon spotting scope from the conducted during September 2003. vantage points. High potential areas were 


\section{Chetri and A. Pokharel / Our Nature (2005)3:56-62}

scanned with the help of spotting scope at least 20 to 30 minutes from the vantage before proceeding to other locations. Once the animals were sighted, a detail record on aspect, slope and habitat types was recorded in the data sheet. The accessible areas where the animals were sighted were visited for checking the floristic composition of the grazing area and GPS coordinate was taken. Table 1 represents the format used for the classification of blue sheep during the survey period.

In addition, interaction with herders $(\mathrm{N}=6)$ was done in order to confirm the occurrence of the species in the lower valley.

\section{Results and Discussion}

Distribution and habitat of Blue Sheep (Pseudois nayaur Hodgson, 1833)

Altogether 395 Blue sheep were recorded during the survey period (Table 2). Of the total 395 blue sheep recorded in twenty one herds only 265 blue sheep were classified according to class category. The percentage of female is comparatively higher $(\mathrm{n}=116)$ than the male $(n=65)$, yearling $(n=32)$ and lamb $(n=52)$. The ratio of male to female observed during the survey is $1: 2$ and the ratio of female to lamb is $2: 1$ respectively.

Group size ranges from 3 to 75 individuals. The mean group size during September was 18.8 individuals. Majority of blue sheep were recorded in the grass land $(87 \%)$ followed by barren land $(11 \%)$ and barren land/cliff (1.3\%). Researcher has found that less productive populations in Nepal inhabit steeper, drier terrains which have been overgrazed by domestic livestock (Schaller 1977). Wilson (1981) indicates a general preference by blue sheep for gentle, grass covered $(60-70 \%$ grass/sedges) slopes with southerly and /or eastern exposures, at altitudes ranging from $3960 \mathrm{~m}$ to $4570 \mathrm{~m}$.
A comparatively higher percentage of blue sheep was recorded in the southern aspect $(54 \%)$ followed by north $(25 \%)$, northeast $(25 \%)$ and west $(10 \%)$. This is mainly due to high quality grass and pasture in south compared to the north as well as the availability of water. Wilson (1981) found a movement of sheep from the south and southwest facing slopes during the autumn to the east and southeast facing slopes during the spring. During the short, cold days of November and December, blue sheep show a preference for the warm south and south west facing slopes (Wilson, 1981). In the present study, data for November presented by Wegge (1976) matches closely for the south, southeast and southwest aspects. Wilson (1981) recorded a total of $65.2 \%$ of blue sheep in autumn observations on the southerly aspects, while Wegge (1976) reported $67.5 \%$ in the Dhorpatan Hunting Reserve. More than $70 \%$ of the blue sheep in the study area was recorded in the slope ranging from 0-30 degree. The altitudinal range of blue sheep distribution is from 4550 to $5481 \mathrm{~m}$. The density of the blue sheep in the study is $5.6 / \mathrm{sq} \mathrm{kms.}$

Distribution and habitat of Tibetan Argali (Ovis ammon hodgsoni Blyth, 1841)

Tibetan argali in Nepal is confined only to the Trans-Himalayan region of the Mustang District (Shah, 2003b). Altogether 77 argalis in four herds were recorded during the survey period (Table 3). The classification of the herds in the study area was difficult due to their timid behavior. Only during one observation at 2:45 hrs one herd was classified $(n=24$, adult male $=15$, female $=5$ and $l a m b=4$ ) while grazing in the meadow area. Group size ranges from 12 to 24 individuals. Shah (2003b) observed 23 argalis in 3 herds (herd size 4, 9 and 10) in the 
M. Chetri and A. Pokharel / Our Nature (2005)3:56-62

Table 1. Format used for the classification of Blue Sheep in the study area

\begin{tabular}{llll}
\hline Class & Age & Horn Size & Height \\
\hline Lamb & $<1$ yrs & $<5 \mathrm{~cm}$ & \\
Yearling & $1-2$ yrs & $<15 \mathrm{~cm}$ & $2 / 3$ of adult female \\
Adult female & & $<20 \mathrm{~cm}$ & $85 \mathrm{~cm}$ \\
Male -I & $2.5 \mathrm{yrs}$ & $25 \mathrm{~cm}$ & Same size as adult female \\
Male -II & $3.5 \mathrm{yrs}$ & $35 \mathrm{~cm}$ & \\
Male -III & $4.5 \mathrm{yrs}$ & $40 \mathrm{~cm}$ & \\
Male -IV & $5.5-7.5 \mathrm{yrs}$ & $45 \mathrm{~cm}$ & \\
Male -V & $>7.5$ & $>50 \mathrm{~cm}$ & \\
\hline Note: Adult Male: Height $90 \mathrm{~cm}$, weight $60 \mathrm{~kg}$ and horn size $78 \mathrm{~cm}$.
\end{tabular}

Note: Adult Male: Height $90 \mathrm{~cm}$, weight $60 \mathrm{~kg}$ and horn size $78 \mathrm{~cm}$.

Table 2. Distribution of blue sheep according to habitat types, aspect and slope. The number in parenthesis indicates total number of individuals.

\begin{tabular}{|c|c|c|c|c|c|}
\hline Habitat types & $\%$ of sightings & Aspect & $\%$ of sightings & Slope & $\%$ of sightings \\
\hline Grassland & $87(345)$ & North & $25(106)$ & $0-10$ & $30(117)$ \\
\hline Barren land/cliff & $1.3(5)$ & South & $54(183)$ & $10-20$ & $13(53)$ \\
\hline \multirow[t]{4}{*}{ Barren land } & $11(45)$ & West & $10(20)$ & $20-30$ & 30 (119) \\
\hline & & North East & $25(86)$ & $30-40$ & $7(29)$ \\
\hline & & & & $40-50$ & $12(46)$ \\
\hline & & & & $>50$ & $8(31)$ \\
\hline Total & $100(395)$ & Total & $100(395)$ & Total & $100(395)$ \\
\hline
\end{tabular}

Table 3. Distribution of Tibetan argali according to habitat types, aspect and slope. The number in parenthesis indicates total number of individuals.

\begin{tabular}{llllll}
\hline Habitat types & \% of sightings & Aspect & \% of sightings & Slope & \% of sightings \\
\hline Dry grassland/meadow & $70(54)$ & South & $55(42)$ & $0-10$ & $39(30)$ \\
Desert Steppe & $30(23)$ & West & $30(23)$ & $10-20$ & $30(23)$ \\
& & North & $16(12)$ & $>20$ & $31(24)$ \\
Total & $\mathbf{1 0 0 ( 7 7 )}$ & Total & $\mathbf{1 0 0}(\mathbf{7 7})$ & Total & $\mathbf{1 0 0}(\mathbf{7 7})$ \\
\hline
\end{tabular}

Table 4. Distribution of Tibetan wild ass according to habitat types, aspect and slope. The number in parenthesis indicates total number of individuals.

\begin{tabular}{llllll}
\hline Habitat types & \% of sightings & Aspect & \% of sightings & Slope & $\%$ of sightings \\
\hline Dry grassland/meadow & $90(47)$ & North & $40(27)$ & $0-10$ & $52(95)$ \\
Desert Steppe & $10(8)$ & South & $40(16)$ & $10-20$ & $3(5)$ \\
& & West & $20(12)$ & $>20$ & $0(0)$ \\
Total & $\mathbf{1 0 0 ( 5 5 )}$ & Total & $\mathbf{1 0 0 ( 5 5 )}$ & Total & $\mathbf{1 0 0 ( 5 5 )}$ \\
\hline
\end{tabular}




\section{Chetri and A. Pokharel / Our Nature (2005)3:56-62}

Damodar Kunda valley between 5200 to $5600 \mathrm{~m}$ in July 2002. The mean group size during September was 19.3 individuals. Majority of the argali were recorded in the southern aspect (55\%), followed by west $(30 \%)$ and north (16\%). Prater (1971) reported that typical habitat of argali presents a wilderness of desolate plains and low undulating sand hill. The argali prefers alpine meadow habitat to Tibetan desert steppe habitat (Schaller, 1998). More than 65\% percent of the argali in the study are recorded at a slope ranging from 0-20 degree. The altitude range of Tibetan argali distribution is from 5339 to $5492 \mathrm{~m}$. The density of the Tibetan argali in the study is $1.1 / \mathrm{sq} . \mathrm{km}$.

Distribution and habitat of Tibetan Wild Ass (Equus kiang Moorcroft, 1841)

A total of 55 individuals of Tibetan wild ass in 10 herds were recorded in the study area (Table 4). All the sightings were made in the upper Damodar Kunda valley. Survey in 2002 recorded a total of 45 individuals of kiang (Shah, 2003a). Group size ranges from 1 to 12 individuals. The mean group size during September was 5.5 individuals. Ninety percent of the sightings were made in the Dry grassland/meadow. The dry grass land/ meadow is dominated by Stipa, Carex and Agrostis grass species and the desert steppe in flat terrain above dominated by cushion plants of Saxifraga and forbs of Kobresia and Saussurea species. Majority of the kiang was recorded in the north $(40 \%)$ and south aspects $(40 \%)$, followed by west $(20 \%)$. Ninety five percent of the kiang in the study area is recorded at a slope ranging from 0-10 degree. The altitudinal range of kiang distribution is from 5187 to $5492 \mathrm{~m}$. The density of the kiang in the study is $0.8 / \mathrm{sq}$. $\mathrm{km}$.

Disturbance and Human Impacts

Broadly the Damodar Kunda Valley can be divided into two broad categories (see Figure 1) Upper Damodar Kunda Valley (50.16 sq. $\mathrm{km})$ and Lower Damodar Kunda Valley (20.99 sq. kms) in terms of both flora and fauna distribution. Most parts of the Upper Damodar Kunda area is barren and desert like. No sufficient forage exists for the wild and domestic ungulates. Such type of open habitat is preferred by kiang and Tibetan argali. In all the observations $(\mathrm{N}=3)$, kiang and Tibetan argali were recorded in the upper valley. The lower valley is moist compared to upper valley and had abundant resources in terms of food/grass, water and space for the wildlife and livestock population. The areas have good pasture including the meadows. Blue sheep were recorded only from the lower valley.

People of Surkhang VDC only have the grazing rights over the pasture of Damodar Kunda area, but these areas are also utilized by people from Chhosher, Chhonup and Lo Manthang VDCs by paying tax to Surkhang VDC during summer season. Generally the herders from Surkhang VDC use this area as pasture and they move to the area during April and May and remain till September. Only goat, sheep and horses are grazed in the valley. The disturbance created by the herders bound the herbivore to shift from the lower to upper valley during the summer seasons. Local herders claim that they had encountered herds of kiang several times in the lower valley during April and May but difficult to find argalis. Researcher has found that habitat disturbance and overgrazing have displaced many altai argali Ovis ammon ammon to marginal pastures in Siilkhemiin Nuruu National Park in western Mongolia (Davarkhbayar et al., 2000; Schuerholz, 2001; Amgalanbaatar et al., 2002). This cannot be ruled out in Damodar Kunda valley 
M. Chetri and A. Pokharel / Our Nature (2005)3:56-62

considering the overflow of livestock. Kiang shifts its grazing ground to upper valley as soon as the herders move to lower valley. In the lower valley, blue sheep and livestock (sheep and goat) are seen grazing together. During the survey period a total of 2800 goat and sheep were counted grazing in the area.

In addition 70 horses from different settlements were using the area. The disturbance is high mainly for five months i.e. from May to September and during this time the habitats of wildlife and livestock overlap. In addition to grazing, this area is also disturbed due to the visit of the pilgrims as this is one of the most important destination and holy place for Hindus. Nearly 200-300 people visit this area from May to September every year for religious rituals.

People say abundant grass was found in and around Damodar Kunda area until few years back. Signs of heavy grazing were also observed on most of the accessible areas. All grazing by livestock is in direct competition with wild herbivores (Wilson, 1981; Fox et al., 1988). Competition is very likely to occur in the area in the case of blue sheep and goat because their foraging habits and regime is similar (Shah, 2003a). Whether there is a competition or dependable relationship among the blue sheep and livestock needs further study. But the disturbances caused by livestock grazing and herders camp have direct impact on the herbivore population of the region. Interviews with the herders revealed that Tibetan Yak herds use the Damodar Kunda area for grazing during the winter. It was confirmed by the presence of Yak dung during May when the herders first visit the valley for grazing. During September 14, 2003, a herd of yak (approx. 60 individuals) was seen grazing near the border area.

Although the Damodar Kunda area is a small valley, it can be considered as a potential habitat for the species studied. Therefore the conservation and management of the area is very important and equally challenging.

\section{Acknowledgements}

Financial support to this study was provided by King Mahendra Trust for Nature Conservation through its Upper Mustang Biodiversity Conservation Project. Rangers of Lo Manthang Unit Conservation Office and the Biodiversity Conservation Project and the community members are acknowledged for their support during the field study.

\section{References}

Amgalanbaatar, S., R.P. Reading, B. Lhagvasuren and N. Batsukh 2002. Argali sheep (Ovis ammon) trophy hunting in Mongolia. Pirineos 157: 129. 150.

Chetri, M. 2004a. Biodiversity Survey in Kekap and Ghemi Lekh (Upper Mustang, 2003. King Mahendra Trust for Nature Conservation, Annapurna Conservation Area Project, Upper Mustang Biodiversity Conservation Project.

Chetri, M. 2004b. Monitoring Survey of the Damodar Kunda Area: A Biodiversity Perspective. King Mahendra Trust for Nature Conservation, Annapurna Conservation Area Project, Upper Mustang Biodiversity Conservation Project.

Davarkhbayar, D., A. Atai and Kh. Beibet 2000. Study on argali (Ovis ammon ammon) distribution, location and resources in some parts of the Mongolian side of the Altai Sayan Ecoregion. WWF Mongolia, Ullanbaatar.

Fox, J.L., S.P. Sinha, R.S. Chundawat, and P.K. Das 1988. A field survey of snow leopard in northwestern India. In: Proceedings of the Fifth International Snow Leopard Symposium (Ed. H. Freeman). Bellevue, Washington, USA and Dehradun, India: International Snow Leopard Trust, and Wildlife Institute of India. pp. 9-111.

Koirala, R. A. and R. Shrestha 1997. Floristic composition of summer habitat and dietary relationships between Tibetan argali (Ovis ammon hodgsonii), naur (Pseudois nayaur) and 
M. Chetri and A. Pokharel / Our Nature (2005)3:56-62

domestic goat (Capra hircus) in the Damodar Kunda region of Upper Mustang in Nepal Himalaya. Agricultural University of Norway, Norway (M.S. Thesis).

Pokharel, A. 2006. An assessment of Rangelands and Pastoral production systems, Upper Mustang, Nepal. Institute of Forestry, Pokhara, Nepal (B.Sc Report).

Prater, S. H. 1971. The Book of Indian Animals. Bombay Natural History Society, Oxford University Press.

Schaller, G. B. 1977. Mountain Monarchs: wild sheep and goats of the Himalayas. University of Chicago press, Chicago.

Schaller, G. B. 1998. Wildlife of the Tibetan Steppe. The University of Chicago Press, USA.

Schuerholz, G. 2001. Community based wildlife management $(C B W M)$ in the Altai Sayan
Ecoregion of Mongolia feasibility assessment: opportunities for and barriers to CBWM. WWFMongolia. Ulaanbaatar, Mongolia. p. 49

Shah, K. B. 2003a. Basic Training in wildlife management techniques and biodiversity survey of the upper Mustang area. Phase-II report. KMTNC/ACAP,Upper Mustang Biodiversity Conservation Project, Pokhara.

Shah, K. B. 2003b. On the distribution and status of Tibetan argali, Ovis ammon hodgsoni Blyth, 1841 in Nepal. Himalayan Journal of Science 1:37-41.

Wegge, P. 1976. Himalayan shikhar reserves: surveys and management proposals. FAO NEP/72/002. Field Document No. 5. Kathmandu, Tribhuvan University Press.

Wilson, P. 1981. Ecology and habitat utilization of Naur, Pseudois nayaur in Nepal. Biological Conservation 21:55-74. 